\title{
When We Are the Delusional Ones
}

\author{
Norman R. Greenberg ${ }^{1}$ (B)
}

Received: 23 February 2021 / Accepted: 9 March 2021 / Published online: 22 April 2021

(C) Academic Psychiatry 2021

"So how do I know that you don't have psychosis?"

I stood stunned for a moment after my patient David, as I'll call him, asked me that question.

"You are right. You don’t," I answered.

For several days, that exchange occupied my thoughts. David arrived on the inpatient psychiatric unit two weeks earlier, presenting with delusions and disorganized behavior. In speaking to him and hearing his history, it became clear that he was experiencing a psychotic episode and he believed that he was completely fine. My medical school lectures prepared me well for this diagnosis. But for several days, I struggled to find a way to convince David that he had an illness, and that we were there to help him.

On the first day of David's admission, I drafted a note for his chart and checked off, "Insight: Poor" from the dropdown menu. I carried on filling out the rest of the mental status exam, as I had been taught. Yet I suddenly found myself staring at the screen, as I grasped the cruelty of David's predicament. My whole life, I could rely on my reason to organize my perceptions, thoughts, and emotions. David's reason had failed him. His thoughts were disorganized. His perceptions deceived him. But worst of all, while David's neuronal circuitry wreaked havoc in his mind, he would be left in the dark with no insight. With a simple click recording his poor insight, I indicated what was David's source of frustration, anger, and sadness: David was convinced that he was fine, imprisoned on the unit against his will with cafeteria food, a couple of books, and a curfew. But to others, he was ill and in need of help.

During morning rounds the next day, I reflected on my conversation with David. I racked my brain for a way to reach him, to persuade him to engage in treatment, and to

Norman R. Greenberg

norman.greenberg@yale.edu

Yale School of Medicine, New Haven, CT, USA consider the possibility that his realities may be delusions. And then my mind wandered to an old Hasidic tale that I read as a child. In the story, a king heard news of a new crop in the kingdom which gave the people a strange case of psychosis. The king consulted his top minister, who advised that they hoard some of the old crop for the king and the minister to maintain their sanity until the strange illness subsides. The king remarked, "But then we will be the only ones who do not eat from the new crop, and then we will be the delusional ones." The king decided that he and his minister would eat from the new crop, contract the delusional disorder, and mark each other's foreheads. "When we see each other, we will be reminded that we are delusional" [1].

Reason and rationality are useless when others operate by different principles. David was alone in his thinking, and to him, everyone else had eaten from the plagued crop. As I sat in the conference room, trusting my reason to formulate ideas, engage with the other staff, or even diagnose David's psychosis, David remained steadfast, trusting his reason. And while I had proof from the literature about psychosis, how it manifests, and what neurobiological disruptions characterize it, I would not be able to convince David that his diagnosis of psychosis was anything more than my own delusion.

Knowing that rational argumentation would be unsuccessful with David, I decided to stop mentioning his diagnosis of psychosis. Instead, I took an interest in his life, his hobbies, and his interests. Rather than attempting to change his beliefs, I tried to show David that we shared a common goal of getting him home safely. Eventually, our team was able to build a trust with him, even if he initially rejected any mention of psychosis. With the newfound trust, David took his medications, attended group therapy, and eventually was discharged.

I smiled as David wished his goodbyes to the staff on the unit, thrilled that we were able to help him. Yet as he left, I realized that many of the challenges I faced with David were not limited to my time on the wards. I thought back to other encounters-like political debates or personal disagreements - when I could not convince others to agree with me. In those moments, I found it tempting to dismiss 
others as misguided or even delusional, ignoring that I too have my own biases and preconceptions, with my own "mark on my forehead." And in those instances, it was most challenging to remember that I have more common interests and similarities with others, than differences. But as with David, though I may not always be able to convince others of my perspective, I hope that I am able to convince others that we share similar goals and that I care about them.

Acknowledgements Thank you to Dr. Randi Hutter Epstein, Samuel Maron, and Ziona Isaacs for reading multiple iterations of this piece and offering invaluable feedback.

\section{Declarations}

Disclosures The author states that there is no conflict of interest.

\section{Reference}

1. Wiesel, E. (1995). Souls on fire: portraits and legends of Hasidic masters. (p. 169). Aronson.

Publisher's Note Springer Nature remains neutral with regard to jurisdictional claims in published maps and institutional affiliations. 